\title{
Pregnancy Outcome in Women with Antiphospholipid Antibodies: Report on a Retrospective Study
}

\author{
Lothar Heilmann, M.D., Ph.D., ${ }^{1}$ Martin Schorch, M.D., ${ }^{1}$ Thomas Hahn, M.D., ${ }^{1}$ \\ Geza Adasz, M.D., ${ }^{1}$ Karin Schilberz, M.D., 1 Cafer Adiguzel, M.D., ${ }^{2}$ \\ and Jawed Fareed, Ph.D. ${ }^{2}$
}

Antiphospholipid syndrome (APS) represents a serious risk factor in pregnancy resulting in several complications, leading to fetal loss and hemostatic complications. In this dedicated report, we describe our experiences in the treatment of pregnancies in patients with APS. The retrospective data from 140 pregnant women were investigated, and the treatment results of 121 patients were recorded. We studied two groups of patients receiving different treatment. The first group $(n=78)$ received the standard therapy with low-weight-molecular heparin (dalteparin $5000 \mathrm{U}$ or certoparin $3000 \mathrm{U}$ daily) and aspirin (100 mg daily) and in the second group $(n=43)$ an additional $0.2 \mathrm{~g} / \mathrm{kg}$ intravenous immunoglobulin (IVIG). Outcomes were $74.3 \%$ and $83.7 \%$ live births in the first group and in the second group, respectively. The abortion rate was similar in both groups $(11.5 \%$ vs. $11.6 \%)$. The late complication rate was lower in the second group $(5.8 \%$ vs. $14.1 \%, p<0.05)$ than in the group with standard therapy. Interestingly, we found a trend to higher percentage $(>12 \%)$ of natural killer $(\mathrm{NK})$ cells in patients with pregnancy complications $(60 \%$ vs. $12 \%, p<0.05)$. Our retrospective data shows an improvement of late pregnancy complications by additional use of IVIG. It is possible that IVIG influences higher NK cell activity in patients with previous pregnancy complications.

KEYWORDS: Antiphospholipid syndrome, pregnancy, low-molecular-weight heparin, certoparin, dalteparin, intravenous immunoglobulins

\begin{abstract}
Antiphospholipid syndrome (APS) is a prothrombotic disorder characterized by arterial and/or venous thrombosis or recurrent abortion in the presence of circulating antiphospholipid antibodies (aPL). These autoantibodies are found in up to $5 \%$ of apparently healthy controls. In contrast, anticardiolipin antibodies $(\mathrm{aCL})$ are
\end{abstract}

found in 5 to $51 \%$ (mean, 15.5\%) and lupus anticoagulant (LA) in 0 to $14 \%$ (mean, 8.3\%) of women with recurrent first-trimester abortion. aPL are also associated with preeclampsia and fetal growth retardation. ${ }^{1-7}$

The clinical management of pregnant woman has advanced during the past decade. Prophylactic dosage of
${ }^{1}$ Institute of Reproduction, Wiesbaden, Germany; ${ }^{2}$ Loyola University Medical Center, Maywood, Illinois.

Address for correspondence and reprint requests: Jawed Fareed, Ph.D., Professor of Pathology \& Pharmacology, Loyola University Medical Center, 2160 S. First Avenue, Maywood, IL 60153 (e-mail: jfareed@lumc.edu).
A Tribute to Eberhard F. Mammen, M.D. (1930-2008); Guest Editor, Emmanuel J. Favaloro, Ph.D., M.A.I.M.S.

Semin Thromb Hemost 2008;34:794-802. Copyright (C) 2008 by Thieme Medical Publishers, Inc., 333 Seventh Avenue, New York, NY 10001, USA. Tel: +1(212) 584-4662.

DOI 10.1055/s-0029-1145261. ISSN 0094-6176. 
aspirin and low-dose heparin use has reduced the pregnancy loss to only up to $40 \%$ of otherwise affected patients. ${ }^{8}$ Low-molecular-weight heparin (LMWH) such as dalteparin and enoxaparin has replaced lowdose heparin and can be administered safely to pregnant women. Despite the use of these agents, many women still fail to deliver a live infant. Intravenous immunoglobulins (IVIGs) and plasma exchange have also been considered. In addition, monoclonal antibodies to B cells, B-cell growth factors, complement pathway modulation, and other plasma proteins such as antithrombin and $\mathrm{C} 1$ esterase inhibitors may also be useful in the management of pregnant women with APS. Aspirin and LMWH are polytherapeutic agents and can modulate the immunopathologic process in this syndrome.

IVIG has been successfully used to reduce the fetal loss in pregnant women with APS, sometimes in addition to steroids and in the presence of immunosuppressive-resistant autoimmune disease. ${ }^{9}$ A combined regimen including IVIG, aspirin, and LMWH provides a polytherapeutic approach in the management of this catastrophic disorder. This study was to determine the safety and efficacy of IVIG in combination with LMWH.

The fetal morbidity and mortality in APS may be due not only to placental thrombosis because of direct effects of aPL on anionic phospholipids and the cofactor $\beta 2$-glycoprotein I ( $\beta 2 \mathrm{GPI})$ on trophoblasts but also to placental inflammation due to complement activation and to impairment of trophoblast function. ${ }^{7,10-12}$

A well-randomized study has shown aspirin and unfractionated heparin (UFH) to have a benefit compared with aspirin alone, with a live birth rate of $78 \%{ }^{13}$ In women with recurrent spontaneous abortion (RSA) and positive aPL, but without treatment, the spontaneous rate of live birth is below $10 \%{ }^{14}$ This led to recommendations in the American College of Chest Physicians guidelines ${ }^{15}$ that obstetric APS would be improved using heparin and aspirin therapy. The combination of LMWH and aspirin compared with aspirin alone did not significantly reduce pregnancy loss. ${ }^{16}$ In contrast, the use of LMWH and aspirin showed an improvement of pregnancy outcome in comparison with UFH and aspirin in a Canadian pilot study. ${ }^{17}$

The relationship between APS and pregnancy complications including fetal loss has been reviewed recently. ${ }^{18-23}$ Ogasawara et $\mathrm{al}^{24}$ found a failure rate of $19.4 \%$ after standard therapy. Tincani et $\mathrm{al}^{25}$ found a complication rate of more than $20 \%$, although standard therapy was associated with a premature birth rate of up to $18.8 \%$, preeclampsia with $11.6 \%$, and intrauterine growth retardation or restriction (IUGR) of $6 \%$. The recurrent complications rate of patients with mediumto high-rate aPL occurred in up to $30 \%$ according to Backos et $\mathrm{al}^{26}$ (30\% were preterm, 22\% were small for gestational age [SGA] babies, and 13.8\% developed preeclampsia or bleeding complications). Many investigators treated such patients with prednisolone, aspirin, and $\mathrm{IVIG}^{27}$ and others with therapeutic doses of LMWH, UFH, or LMWH and IVIG. ${ }^{28}$ In the earlier guidelines for the treatment of APS, ${ }^{18,25,29,30}$ the additional use of IVIG in cases with normal karyotyping and when standard therapies have failed was discussed. ${ }^{31-34}$ It is possible that this treatment concept influenced also the elevated level of peripheral natural killer cells (pNK-cells) in women with APS and pregnancy complications. ${ }^{35,36}$ Clinical studies ${ }^{37-40}$ have demonstrated that increased levels of pNK cells are associated with RSA, and many investigators ${ }^{41-44}$ have used these cells as markers for the selection of patients for IVIG therapy.

Human pNK cells are divided into two mean populations based on the type and strength of immunofluorescence staining: around $95 \%$ of $\mathrm{pNK}$ cells are $\mathrm{CD}_{5} 6^{+} \operatorname{dim} \mathrm{CD} 16^{+}$, in contrast with around $5 \%$ of pNK cells with $\mathrm{CD} 56^{+}$bright $\mathrm{CD} 16^{-} . \mathrm{CD} 56^{+}$dim $\mathrm{CD} 16^{+}$pNK cells are highly cytotoxic and express members of the killer Ig-like receptor (KIR). CD16 do not express KIR and have a low toxicity function. Decidual (dNK) or uterine (uNK) NK cells are mostly $\mathrm{CD} 56^{+}$bright $\mathrm{CD} 16^{-}$and have a low toxicity against decidual cells, but a small proportion of the dNK cells are of the $\mathrm{CD} 56^{+} \mathrm{CD} 16^{+}$phenotype with a high cytotoxic activity. In the literature, two explanations exist for the association of pNK cells with dNK cells. First, CD16 pNK cells migrate to the uterus and undergo further differentiation by extravillous trophoblasts. Second, transforming growth factor $\beta$ (TGF- $\beta$ ) - produced and expressed in decidual stroma-influences the conversion of $\mathrm{CD}_{16}{ }^{+}$pNK cells to CD16 ${ }^{-}$pNK cells. ${ }^{45}$ These findings are in agreement with the results of Sacks et $\mathrm{al}^{46}{ }^{46}$ who also found in their recent study a strong correlation between pNK cells and dNK cells in women with RSA and repeated reproduction failure.

An important clinical point is the question of how dNK cells are activated and attack the trophoblast. Recent research still in progress explains this phenomena as due to a lack of inhibition of $\mathrm{KIR}^{32,47-49}$ or an unbalance between inhibition and activation of KIR. ${ }^{50-52}$ These experimental results are not uniform, and two working groups ${ }^{53,54}$ have shown contrary data.

The characteristics of the obstetric APS are defined in the Sapporo classification from 1999. ${ }^{55}$ These criteria were tested by Lockshin et $\mathrm{al}^{56}$ to have a sensitivity and specificity of $71 \%$ and $98 \%$, respectively. Clinical experience includes the determination of IgG and IgM-anti- $\beta 2$-glycoprotein I (a $\beta 2 \mathrm{GPI}$ ) in the laboratory criteria of APS since $1997 .{ }^{57}$ The results obtained from most investigators indicate that use of aß2GPI may provide only additional information for the diagnosis of APS. Franklin et $\mathrm{al}^{58}$ showed $22.2 \%$ positive $\mathrm{IgG}$ antibodies to a $32 \mathrm{GPI}$ in APS. However, 
Carmo-Pereira et $\mathrm{al}^{59}$ and Chong et $\mathrm{al}^{60}$ showed no correlation to the aCL status and $\mathrm{a} \beta 2 \mathrm{GPI}$.

\section{MATERIALS AND METHODS}

\section{Patients}

Between 1988 and 2008, 156 patients were diagnosed with positive aCL or LA with known outcome of pregnancy. After repeated measurement after 6 weeks, 140 women were considered to have a true APS. Sixtytwo women were given standard treatment in their previous pregnancies with LMWH (dalteparin 2500 to $5000 \mathrm{U}$ or certoparin $3000 \mathrm{U}$ daily) or UFH $(2 \times 5000 \mathrm{U}$ calciparin) together with $100 \mathrm{mg}$ aspirin. Three women received additional cortisone $(20 \mathrm{mg}$ daily until 12 th week of gestation), and 78 women had not received therapy for a previous pregnancy (Table 1). Sixty-three women had ongoing recurrent abortion (21 women with 3 abortions, 20 women with 4 abortions, and 22 women with 5 or more abortions), and 35 women had severe preeclampsia $<34$ th week of gestation or a hemolytic anemia, elevated liver enzymes, and low platelet count (HELLP)-syndrome identified within their clinical history. In 21 patients, there was a late abortion after the 12 th week of gestation, and 19 women had an uncomplicated pregnancy with a live-born baby. The nomenclature for description of recurrent abortion according to Farquharson et al was used. ${ }^{33}$ No additional triggering factors, such as hereditary thrombophilias or anatomic or genetic abnormalities, occurred during this study.

At the time of diagnosis of a new pregnancy, all women were started with LMWH (3000 anti-Xa U certoparin or $5000 \mathrm{U}$ dalteparin daily) together with 100 $\mathrm{mg}$ aspirin daily. In the group previously treated with standard therapy but with treatment failure, additional $0.2 \mathrm{~g} / \mathrm{kg}$ IVIG was given until 30 to 32 weeks of gestation. The dosages were in agreement with the recommendations of Kiprov et $\mathrm{al}^{61}$ and Stojanovich et al. ${ }^{62}$

The aim of this retrospective analysis was to describe our experiences in the treatment of APS preg- nancies. We included all information about pregnancy outcome, such as recurrent abortion, preeclampsia, and fetal death. Additionally, classic side effects of all drugs used was documented. All patients gave written informed consent for inclusion in this study.

\section{Blood Sampling}

Blood samples were collected from patients during their first visit after identification of a history of recurrent spontaneous abortion (3 abortions or more), severe preeclampsia, and/or treatment failure after standard therapy of APS. Plasma samples were anticoagulated in $1 / 10$ volume with $3.2 \%$ sodium citrate and stored at room temperature not more than 1 hour prior to double centrifugation at $3000 \times g$ for 15 minutes. The resulting platelet-poor plasma was stored at $-70^{\circ} \mathrm{C}$ until analysis.

\section{Laboratory Methods}

IgG (positive titers > $20 \mathrm{IgG}$ phospholipids (GPL) U/ $\mathrm{mL}$ ) and $\operatorname{IgM}$ (positive titers $>20 \operatorname{IgM}$ phospholipids (MPL) U/ml) aCL assay was performed using ELISA assays (Pharmacia Diagnostics, Freiburg, Germany). The LA was assayed according to the phospholipiddependent method (using "Screen" and "Confirm" simplified dilute Russell's viper venom test [DRVVT]; Instrumentation Laboratories, Munich, Germany). The test was measured on fresh plasma samples and was considered positive when LA Screen/LA Confirm was more than 1.20 (using data from Brandt et $\mathrm{al}^{19}$ and Bertolaccini et $\left.\mathrm{al}^{57}\right)$.

aß2GPI was determined by ELISA assay from Pharmacia Diagnostics (positive values $>20 \mathrm{U} / \mathrm{mL}$ ). Measurements of aPL were repeated after 6 weeks.

$\mathrm{NK}$ cells $\mathrm{CD} 56^{+} \mathrm{CD} 16^{+}$were determined by flow cytometry after separation of blood using Ficoll-Paque gradient at $4^{\circ} \mathrm{C}$ and the mononuclear fraction, which was aspirated off the gradient and then washed twice with phosphate-buffered saline before staining. NK cells are determined using color flourescence-activated cell sorting (FACS) scan after staining with monoclonal antibodies

Table 1 Pregnancy Outcome Dependence on Treatment (Basic Data)

\begin{tabular}{llll}
\hline & $\begin{array}{l}\text { Outcome with } \\
\text { Treatment } \\
(\mathbf{N = 6 2 )}\end{array}$ & $\begin{array}{l}\text { Outcome without } \\
\text { Treatment } \\
(\mathbf{N = 7 8 )}\end{array}$ & NS \\
\hline Age (years) & $30 \pm 5$ & $28 \pm 4$ & $<0.02$ \\
Diagnosis & & 52 & $<0.05$ \\
RSA, $n$ & 11 & 14 & $<0.05$ \\
Late abortion, $n$ & 7 & 12 & $<$ \\
Severe preeclampsia, $n$ & 23 & $12(15.4)$ & $<0.05$ \\
Uncomplicated pregnancies, $n$ & 19 & & \\
Live birth, $n(\%)$ & $42(67.7)$ & & \\
\hline
\end{tabular}

NS, not significant. 
Table 2 Pregnancy Outcome after Two Different Treatment Regimens

\begin{tabular}{|c|c|c|c|}
\hline \multirow[b]{2}{*}{ Diagnosis } & \multicolumn{2}{|c|}{ Treatment } & \multirow[b]{2}{*}{$p$ Value } \\
\hline & $\begin{array}{l}\text { LMWH + Aspirin } \\
(N=78)\end{array}$ & $\begin{array}{l}\text { LMWH }+ \text { Aspirin + IVIG } \\
(\boldsymbol{N}=\mathbf{4 3})\end{array}$ & \\
\hline Abortion early, $n(\%)$ & $5(6.4)$ & $3(6.9)$ & NS \\
\hline Abortion late, $n(\%)$ & $4(5.1)$ & $2(4.7)$ & NS \\
\hline Preeclampsia, $n(\%)$ & 9 (11.5) & $1(2.3)$ & $<0.05$ \\
\hline Fetal death, $n(\%)$ & $2(2.6)$ & $1(2.3)$ & NS \\
\hline Live birth (uncomplicated delivery), $n(\%)$ & $59(74.3)$ & $36(83.7)$ & NS \\
\hline
\end{tabular}

NS, not significant.

to $\mathrm{CD} 16, \mathrm{CD} 56$, and $\mathrm{CD} 8$. The normal values were 3 to $12 \%$ according to Beer et al. ${ }^{41}$

\section{Statistical Analysis}

The statistical analysis was performed by means of a computer-assisted statistical program. Differences between groups were calculated with the Mann-Whitney test. $p$ values $<0.05$ were reported to be statistically significant.

\section{RESULTS}

To date, a total of 78 untreated patients have been reported with $15.4 \%$ live births (Table 1) and $67.7 \%$ live births after standard therapy in 62 patients. In addition, 43 women treated with LMWH and aspirin and IVIG (second treatment) delivered viable infants in $83.7 \%$ of cases compared with $78.0 \%$ after standard therapy (first treatment, Table 2), and $86.4 \%$ versus $86.0 \%$ after inclusion of preeclampsia. The abortion rate in the treatment group was $29.0 \%$, and $54.7 \%$ of the women with live-born babies had a diagnosis of preeclampsia. Interestingly, the group without previous treatment had a higher abortion rate of $84.6 \%$, and all live-born babies resulted from women with severe preeclampsia.

The values of aCL, a $\beta 2 \mathrm{GPI}$, and LA showed no differences between different groups (Table 3). Positive
aß2GPI were low in all groups. The percentage of $\mathrm{pNK}$ cells $>12$ were between $55 \%$ and $65 \%$ in both groups with pregnancy complications. These values were statistically higher $(p<0.05)$ than the rate of pNK cells of $>12 \%$ in uncomplicated pregnancies.

The distribution of $\mathrm{CD} 56^{+} \mathrm{CD} 16^{+}$cells in peripheral blood showed a trend to more live-born cases in association with low levels of NK cells and higher concentrations in patients with pregnancy complications (Fig. 1, Table 4). The number of women in each group was too small for a strong statistical analysis. LMWH and IVIG were both well tolerated. A typical infusion reaction characterized by flushing and headache was seen in one patient. This reaction could be avoided by stopping the infusion. In 18 patients, we observed bleeding in early pregnancy, and the bleeding stopped after removing aspirin or LMWH. We observed one skin reaction after dalteparin injection of $5000 \mathrm{U}$ per day, but without thrombocytopenia or other signs of heparininduced side effects (i.e., HIT II) (Table 5).

\section{DISCUSSION}

In our retrospective study, the pregnancy outcome in APS patients with failure after standard therapy was compared with patients after first and standard therapy with LMWH and aspirin. The optimal therapy of pregnant women with fetal loss and moderate and high titers of aPL is controversial. Recommendations for use

Table 3 Distribution of aCL, aß2GPI, LA, and NK Cells in Different Patient Groups after First Diagnosis

\begin{tabular}{|c|c|c|c|c|}
\hline aPL & $\begin{array}{l}\text { Abortions } \\
(N=84)\end{array}$ & $\begin{array}{l}\text { Preeclampsia/ } \\
\text { HELLP } \\
(\boldsymbol{N}=35)\end{array}$ & $\begin{array}{l}\text { Uncomplicated } \\
\text { Pregnancies } \\
(N=19)\end{array}$ & $p$ Values \\
\hline aCL-IgG and IgM, $n(\%)$ & $17(20.2)$ & $5(14.2)$ & $5(26.3)$ & NS \\
\hline aCL-IgG alone, $n(\%)$ & $50(59.5)$ & $22(62.9)$ & $11(57.8)$ & NS \\
\hline aCL-IgM alone, $n(\%)$ & 7 (8.3) & $3(8.5)$ & 0 & NS \\
\hline LA alone, $n(\%)$ & $6(7.1)$ & $1(2.8)$ & $2(10.5)$ & NS \\
\hline LA with aCL, $n(\%)$ & $1(1.2)$ & $3(8.5)$ & $1(5.8)$ & NS \\
\hline aß2GPI alone, $n(\%)$ & $3(3.6)$ & $1(2.8)$ & 0 & NS \\
\hline NK cells $\mathrm{CD}^{2} 6^{+} \mathrm{CD}^{+} 6^{+}, \%$ & 65 & 55 & 12 & $<0.05$ \\
\hline
\end{tabular}

NS, not significant. 


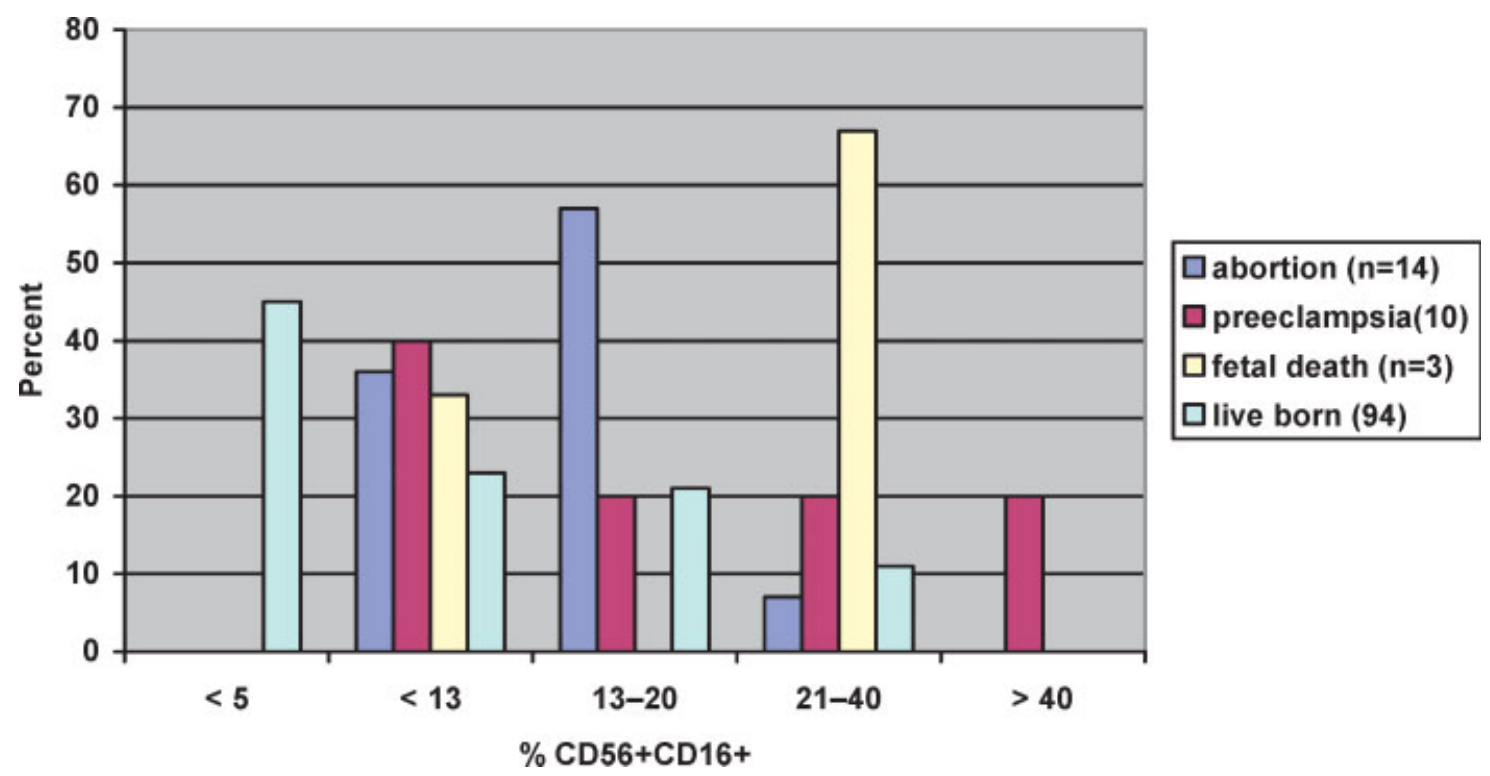

Figure 1 Distribution of NK cells $\left(\mathrm{CD}^{+} 6^{+} \mathrm{CD} 16^{+}\right)$in treated patients $(N=121)$.

of LMWH and aspirin to treat APS in pregnancy were examined in only two trials involving 140 patients. ${ }^{13,63}$ The treatment was started with aspirin (100 mg daily) if a positive pregnancy test occurred and with LMWH when a viable intrauterine pregnancy was documented and continued until delivery and 6 weeks postpartum.

The problems in most of the studies relate to the inclusion criteria. We included only patients with moderate and high titers of $\mathrm{aCL}$ and with specificity to aß2GPI. ${ }^{49}$ Lynch et $\mathrm{al}^{63}$ found for patients with fetal loss an incidence of $27.7 \%$ positivity for $\operatorname{IgG}(\mathrm{aCL}$ ), $5.0 \%$ positivity for $\operatorname{IgM}(\mathrm{aCL})$, and $15.5 \%$ positivity for LA. In contrast with a previous investigation by Kaira et al, ${ }^{64}$ Lockwood et $\mathrm{al}^{65}$ showed an increased level of aCL-IgM between $18 \%$ and 30\%. In a normal pregnant population, Fialova et $\mathrm{al}^{66}$ indicated an incidence of 5.1\% positivity (>20.0 GPL) for IgG antibodies and 7.3\% positivity for IgM (>10 MPL) antibodies (aCL). Aoki et $\mathrm{al}^{37}$ found $\mathrm{IgG} / \mathrm{IgM}$ antibodies (aCL) in $14 \%$ and $\mathrm{IgG}$ antibodies in $12 \%$ of patients with a strong association of IgG antibodies to fetal loss. Branch et $\mathrm{al}^{67}$ found in severe preeclampsia $16 \%$ positive for $\mathrm{IgG}$ antibodies and in fetal loss $16 \%$ positive for $\operatorname{IgG}$ antibodies and 5\% positive for IgM antibodies. In another article published in $2000,{ }^{66}$ the incidence of ${ }^{a C L}-\operatorname{IgG}$ and $\operatorname{IgM}$ in pregnant women was very low (between $2.5 \%$ and $5 \%$ )

Table 4 Pregnancy Outcome and the Influence of the NK Cells

\begin{tabular}{|c|c|c|c|c|c|c|}
\hline \multirow[b]{3}{*}{ Diagnosis } & \multicolumn{6}{|c|}{ Percentage of NK Cells (\%) } \\
\hline & $0-5$ & $6-12$ & $>12$ & $13-20$ & 21-40 & $>40 \%$ \\
\hline & \multicolumn{6}{|c|}{ Percentage of Patients Yielding Each Level of NK Cells (\%) } \\
\hline Abortion $(N=14)$ & 0 & 5 & 65 & 8 & 4 & 0 \\
\hline Preeclampsia $(N=10)$ & 0 & 4 & 55 & 2 & 2 & 2 \\
\hline Fetal death $(N=3)$ & 1 & 0 & 67 & 2 & 0 & 0 \\
\hline Live birth $(N=94)$ & 42 & 22 & 32 & 20 & 10 & 0 \\
\hline
\end{tabular}

Table 5 Side Effects after Different Treatment Regimens

\begin{tabular}{lll}
\hline & \multicolumn{1}{c}{ Treatment Arm } \\
\cline { 2 - 3 } Side Effects & LMWH + Aspirin & LMWH + Aspirin + IVIG \\
\hline Bleeding in early pregnancy & $n=10$ & $n=8$ \\
& No further bleeding after cessation of aspirin & No bleeding after cessation of aspirin or LMWH \\
Skin reaction & $n=1$ (Recurrence after cessation of treatment) & 0 \\
Flush & 0 & $n=1$ (Late reaction and spontaneous recurrence) \\
\hline
\end{tabular}


and showed no association with the severity of disease. An investigation of Barbui et $\mathrm{al}^{68}$ indicated a high incidence of LA (positive in 14\% of women with abortions). Ogasawara et $\mathrm{al}^{24}$ found the prevalence of antibodies to be $5.4 \% \operatorname{IgG}$ and $\operatorname{IgM}$ antibodies and $11.3 \%$ for LA. Similar results were reported by Soltesz et $\mathrm{al}^{69}$ with $14.5 \% \mathrm{LA}$ and $26.1 \% \mathrm{IgG}$ antibodies alone and $39.0 \% \mathrm{IgM}$ antibodies alone, respectively, and both antibodies together in $20.3 \%$. In these previously reported studies, no investigators have described an increase in NK cells in women with APS. ${ }^{17,66}$ Konova et al ${ }^{70}$ showed that $64.3 \%$ of women with recurrent fetal loss and APS had elevated NK cells of $>12 \%$.

Lynch et $\mathrm{al}^{63}$ also found more antibodies between 20 and $30 \mathrm{U} \mathrm{IgG}$ than in higher concentrations reported by Konova et al. ${ }^{70}$ The identification of LA or LA and aCL together was higher in preeclamptic patients and lower in the abortion group and also lower in women with uncomplicated pregnancies. The main problem with these findings is the fluctuations in antibodies during pregnancy, ${ }^{21,48,63,69}$ and it is possible that persistent high levels of aCL or LA in women with APS are associated with higher pregnancy complications. Unfortunately, we could not repeat all measurements of aCL during pregnancy. We found antibodies directly against $\beta 2 G P I$, but the clinical relevance of this finding is uncertain. ${ }^{71}$ In the patient group with the additional therapeutic use of IVIG, the late pregnancy complications were lower (statistically significant) than in the LMWH and aspirin population. These findings are in agreement with the results of Branch et al, ${ }^{67,71}$ Vaquero et $\mathrm{al},{ }^{72}$ and Valensie et al. ${ }^{73} \mathrm{~A}$ difference in the abortion rate was not demonstrated. These results are in agreement with Carp et $\mathrm{al}^{8}$ that IVIG did not influence the abortion rate in comparison with LMWH, but the incidence of preeclampsia was lower than that during LMWH and aspirin treatment. Heparin appears to protect pregnancies and prevented abortions by inhibition of the complement system rather than by the anticoagulation system. ${ }^{74}$ Expression of different cytokines leads to an increase of activated killer cells, which attack the trophoblast. It is possible that IVIG had a stronger influence of cytokine-activated killer cells in late pregnancy than did LMWH, because anticoagulation is not sufficient to prevent pregnancy complications. ${ }^{71,72}$ Recent data have shown that NK cells have a direct cytotoxic effect against trophoblast cells by interaction with the activating KIR receptor. ${ }^{75}$ Another mechanism of action for IVIG is that anti-idiotypic antibodies, which may be present in the IVIG preparation, bind autoantibodies or downregulate B-cell receptors or bind receptors of regulatory $\mathrm{T}$ cells resulting in suppression of cytokine production and NK cell activity. ${ }^{9,76}$ We could demonstrate a subgroup of APS women with RSA and high percentage of NK cells. This finding is in agreement with Perricone et al, ${ }^{77}$ which demonstrated that
$52 \%$ of APS patients had increased levels of NK cells of $\mathrm{CD} 56^{+} \mathrm{CD} 16^{+}$type. The association of high pNK cells and poor pregnancy outcome (preeclampsia) was reviewed by Sargent et al. ${ }^{78}$ The authors summarized that aberrant NK cells activation locally or systemically (peripheral blood) may be the cause of pregnancy complications.

In conclusion, the additional use of IVIG in women with treatment failure in our retrospective observational study indicates a decrease of pregnancy complications but no differences in the abortion rate. Because there are only rare side effects of IVIG in combination with LMWH and aspirin, IVIG may be a suitable alternative therapy for women with repeated late pregnancy complications, early pregnancy failure, and APS. Despite the important fact that IVIG can cross the placenta, no fetal adverse effects have been reported in studies performed on patients suffering hematologic and autoimmune disorders. ${ }^{79}$

There are no clear recommendations regarding optimal therapy in failure of treatment or refractory cases; however, additional IVIG with clinical judgment will be important to manage such pregnancies. Further studies with NK cells are needed for the evaluation of a strong recommendation in the treatment of refractory cases.

\section{IN APPRECIATION}

Both Dr. Eberhard Mammen and Dr. Rodger Bick had a strong interest in the diagnosis and management of APS in pregnant women. They covered this topic together in many educational workshops and provided an authoritative account of this syndrome. Through their effort, there was an increased awareness and development of standard-of-care approaches around the globe. The authors are strongly influenced by their teachings, and the current work is because of the leadership and directions of these two wonderful physicians. Their teaching will continue to impact this area in years to come.

\section{REFERENCES}

1. Birdsall MA, Lockwood GM, Ledger WL. Antiphospholipid antibodies in women having in-vitro fertilization. Hum Reprod 1996;11:1185-1189

2. Carp HJA. Antiphospholipid syndrome in pregnancy. Curr Opin Obstet Gynecol 2004;16:129-135

3. Cervera R, Piette JC, Font J, Khamashta MA; for the EuroPhospholipid project group. Antiphospholipid syndrome. Arthritis Rheum 2002;46:1019-1027

4. Katano K, Aoki A, Sasa H, et al. $\beta$ 2-glykoprotein1dependent anticardiolipin antibodies as a predictor of adverse pregnancy outcomes in healthy pregnant women. Hum Reprod 1996;11:509-512 
5. Pattison NS, Chamley LW, McKay EJ, et al. Antiphospholipid-antibodies in pregnancy: prevalence and clinical association. Br J Obstet Gynaecol 1993;100:909-913

6. Schleussner E. Impact of the antiphospholipid syndrome on complications during pregnancy. Transfus Med Hemother 2006;33:486-492

7. Yasuda M, Takakuwa K, Tokunaga A, Tanaka K. Prospective studies of the association between anticardiolipin antibody and outcome of pregnancy. Obstet Gynecol 1995;86: 555-559

8. Carp HJA. Intravenous immunoglobulin: effect on infertility and recurrent pregnancy loss. Israel Medical Association Journal 2007;9:877-880

9. Clark DA, Coulam CB, Stricker RB. Is intravenous immunoglobulins (IVIG) efficacious in early pregnancy failure? A critical review and metaanalysis for patients who fail in vitro fertilization and embryo transfer(IVF) $\mathrm{J}$ Assist Reprod Genet 2006;23:1-13

10. Canesi B, Brucato A. Antiphospholipid antibodies and pregnancy. Haematologica Reports 2005;1:6-12

11. Galli M, Barbui T. Antiphospholipid antibodies and pregnancy. Best Pract Res Clin Haematol 2003;16:211-225

12. Salmon JE, de Groot PG. Pathogenic role of antiphospholipid antibodies. Lupus 2008;17:405-411

13. Kutteh WH. Antiphospholipid-antibody-associated recurrent pregnancy loss. Treatment with heparin and low dose aspirin is superior to low dose aspirin alone. Am J Obstet Gynecol 1996;174:1584-1589

14. Vashisht A, Regan L. Antiphospholipid syndrome in pregnancy—an update. J R Coll Physicians (Edinburg) 2005; 35:337-339

15. Bates SM, Greer IA, Hirsh J, Ginsberg JS. Use of antithrombotic agents during pregnancy: the Seventh ACCP Conference on antithrombotic and thrombolytic therapy. Chest 2004;127(suppl 3):627-644

16. Empson M, Lassere M, Craig JC, Scott JR. Recurrent pregnancy loss with antiphospholipid antibody. A systematic review of therapeutic trials. Obstet Gynecol 2002;99:135144

17. Stephenson MD, Ballem PJ, Tsang P, et al. Treatment of antiphospholipid antibody syndrome (APS) in pregnancy: a randomized pilot trial comparing low molecular heparin to unfractionated heparin. J Obstet Gynaecol Canada 2004;26: 729-734

18. Branch W, Khamashta MA. Antiphospholipid syndrome: obstetric diagnosis. Management and controversies. Obstet Gynecol 2003;101:1333-1344

19. Brandt JT, Triplett DA, Alving B, Scharrer I. Criteria for the diagnosis of lupus anticoagulants: an update. Thromb Haemost 1995;74:1185-1190

20. Lim W, Crowther MA, Eikelboom JW. Management of antiphospholipid antibody syndrome: a systematic review. JAMA 2006;295:1050-1057

21. Lynch AM, Rutledge JH, Stephens JK, et al. Longitudinal measurement of anti-cardiolipin antibodies during normal pregnancy:a prospective study. Lupus 1995;4:365-369

22. Tincani A, Bazzani C, Zingarelli S, Lojacono A. Lupus and the antiphopsholipid syndrome in pregnancy and obstectrics: clinical characteristics, diagnosis, pathogenesis and treatment. Semin Thromb Hemost 2008;34:267-273

23. Pierangeli SS, Chen PP, Raschi E, et al. Antiphospholipid antibodies and the antiphospholipid syndrome: pathogenic mechanisms. Semin Thromb Hemost 2008;34:236-250
24. Ogasawara M, Sasa H, Katano K, et al. Recurrent abortion and moderate or strong antiphospholipid antibody production. Int J Gynaecol Obstet 1998;62:183-188

25. Tincani A, Branch W, Levy RA, et al. Treatment of patients with antiphospholipid syndrome. Lupus 2003;12:524-529

26. Backos M, Rai R, Baxter N. Pregnancy complications in women with recurrent miscarriage associated with antiphospholipid antibodies treated with low dose aspirin and heparin. Br J Obstet Gynaecol 1999;106:102-107

27. Cowchock S. Prevention of fetal death in the antiphospholipid antibody syndrome. Lupus 1996;5:467-472

28. Clark AL, Branch DW, Silver RM. Pregnancy complicated by the antiphospholipid syndrome: outcomes with intravenous immunoglobulin therapy. Obstet Gynecol 1999;93:437441

29. Alarcon-Segovia D, Boffa MC, Branch W, et al. Prophylaxis of the antiphospholipid syndrome: a consensus report. Lupus 2003;12:499-503

30. Greaves M, Cohen H, MacHin SJ, Mackie I. Guidelines on the investigation and management of the antiphospholipid syndrome. Br J Haematol 2000;109:704-715

31. Chang $\mathrm{P}$, Millar $\mathrm{D}$, Tsang $\mathrm{P}$, et al. Intravenous immunoglobulin in antiphospholipid syndrome and maternal floor infarction when standard treatment fails: a case report. Am J Perinatol 2006;23:125-129

32. Cowchock S. Treatment of antiphospholipid syndrome in pregnancy. Lupus 1998;17:95-97

33. Farquharson RG, Jauniaux E, Exalto N. Updated and revised nomenclature for description of early pregnancy events. Hum Reprod 2005;20:3008-3011

34. Huong DLT, Wechsler B, Bletry O, Vaunthier-Brouzes D, Lefebvre G, Piette J-C. A study of 75 pregnancies in patients with antiphospholipid syndrome. J Rheumatol 2001;28: 2025-2030

35. Carp HJA, Asherson RA, Shoenfeld Y. Intravenous immunglobulin in pregnancies complicated by the antiphospholipid syndrome: what is its role. J Clin Rheumatol 2001; 7:291-294

36. Perricone C, Carolis CD, Giacomelli R, et al. High levels of NK cells in the peripheral blood of patients affected with antiphospholipid syndrome and recurrent spontaneous abortion: a potential new hypothesis. Rheumatology 2007;46: 1574-1578

37. Aoki K, Hayashi Y, Hirao Y, Yagami Y. Specific antiphospholipid antibodies as a predictive variable in patients with recurrent pregnancy loss. Am J Reprod Immunol 1993; 29:82-87

38. Emmer PM, Nelen WLDM, Steegers EAP, Hendriks JCM, Veerkoek M, Joosten I. Peripheral natural killer cell cytotoxicity and CD56pos CD16 pos cells increase during early pregnancy in women with a history of recurrent spontaneous abortion. Hum Reprod 2000;15:1163-1169

39. Van den Heuvel MJ, Crystal GP, Hatta K, Han VK, Clark DA. Decline in number of elevated blood CD3+ CD56+ NKT cells in response to intravenous immunoglobulin treatment correlates with successful pregnancy. Am J Reprod Immunol 2007;58:447-459

40. Veenstra van Nieuwenhoven AL, Heinemann MJ, Faas MM. The immunology of successful pregnancy. Hum Reprod Update 2003;9:347-357

41. Beer AE, Kwaak TY, Ruiz JE. Immunophenotypic profiles of peripheral blood lymphocytes in women with recurrent pregnancy loss and infertile women with multiple failed in 
vitro fertilization cycles. Am J Reprod Immunol 1996;35: 376-382

42. Coulam CB, Beaman KD. Reciprocal alteration in circulating TJ6+ CD19+ and TJ6+ CD56+ leukocytes in early pregnancy predict success or miscarriage. Am J Reprod Immunol 1995;34:219-224

43. Kwak-Kim J, Gillman-Sachs A. Clinical implication of natural killer cells and reproduction. Am J Reprod Immunol 2008;59:388-400

44. Vila P, Hernandez MC, Lopez-Fernandez MF. Prevalence, follow-up and clinical significance of the anticardiolipin antibodies in normal subjects. Thromb Haemost 1994;72: 209-213

45. Keskin DB, David S, Allan J, et al. TGFß promotes conversion of CD16+ peripheral blood NK cells into CD16-NK cells with similarities to decidual NK cells. Proc Natl Acad Sci U S A 2007;104:3378-3383

46. Sacks G, Fay L, Smith S, Russell P, Chapman M. NK cells analysis in women with recurrent reproductive failure; there is a clinical correlation between peripheral blood and endometrial biopsy samples. The Royal Australian and New Zeeland College of Obstetricians and Gynecologists 2007; 47(Suppl 1):A27-28

47. Varla-Leftherioti M, Spyropoulou-Vlachou M, Niokou D et al. Natural killer (NK) cell receptors repertoire in couples with recurrent spontaneous abortions. Am J Reprod Immunol 2003;49:183-191

48. Varla-Leftherioti M, Spyropoulou-Vlachou M, Keramitsoglou T. Lack of the appropriate natural killer cell inhibitory receptors in women with spontaneous abortion. Hum Immunol 2005;66:65-71

49. Wilson WA, Harris N. Management of antiphospholipid syndrome in pregnancy. In: Carp HJA, ed. Recurrent Pregnancy Loss. London, United Kingdom: Informa Healthcare; 2007:119-125

50. Vacca P, Pietra G, Falco M, et al. Analysis of natural killer cells isolated from human decidua: evidence that 2B4(CD244) functions as an inhibitory receptor and blocks NK-.cell function. Blood 2006;108:4078-4085

51. Yamada H, Shimada S, Kato EH, et al. Decrease in a specific killer cell immunoglobulin-like receptor on peripheral natural killer cells in women with recurrent spontaneous abortion of unexplained etiology. Am J Reprod Immunol 2004;51:241247

52. Yamada H, Shimada S, Morikawa M, et al. Divergence of natural killer cell receptor and related molecule in the decidua from sporatic miscarriage with normal chromosome karyotype. Mol Hum Reprod 2005;11:451-457

53. Hiby SE, Regan L, Lo W, Farrell L, Carrington M, Moffet A. Association of maternal killer-cell immunoglobulin-like receptor and parental HLA-C genotypes with recurrent miscarriage. Hum Reprod 2008;23:972-976

54. Witt CS, Goodridge J, Gerbase-Delina MG, Daher S, Christiansen FT. Maternal KIR repertoire is not associated with recurrent spontaneous abortion. Hum Reprod 2004;19: 2653-2657

55. Wilson WA, Gharavi AE, Koike $\mathrm{T}$, et al. International consensus statement on preliminary classification criteria for definite antiphospholipid syndrome. Report of an international workshop. Arthritis Rheum 1999;42:1309-1311

56. Lockshin MD, Sammaritano LR, Schwartzman S. Validation of the Sapporo criteria for antiphospholipid syndrome. Arthritis Rheum 2000;43:440-443
57. Bertolaccini ML, Khamashta MA. Laboratory diagnosis and management challenges in the antiphospholipid syndrome. Lupus 2006;15:172-178

58. Franklin RD, Hollier N, Kutteh WH. $\beta 2-$ Glycoprotein 1 as a marker of antiphospholipid syndrome in women with recurrent pregnancy loss. Fertil Steril 2000;73:531-535

59. Carmo-Pereira S, Bertolaccini ML, Escudero-Contres A, et al. Value of IgA anticardiolipin and anti-B-2 glycoprotein 1 antibody testing in patients with pregnancy morbidity. Ann Rheum Dis 2003;62:540-543

60. Chong P, Matzner W, Ching W. Correlation between beta2-glycoprotein antibodies and antiphospholipid antibodies in patients with reproductive failure. Am J Reprod Immunol 1998;40:414-417

61. Kiprov DD, Nachtigall RD, Weavers RC, Jacobson A, Main EK, Garvoy MR. The use of intravenous immunoglobulin in recurrent pregnancy loss associated with combined alloimmune and autoimmune abnormalities. Am J Reprod Immunol 1996;36:228-234

62. Stojanovich L, Mikovic Z, Mandic V, Popvid-Kuzmanovic D. Treatment of antiphospholipid-syndrome in pregnancy with low dose of intravenous immunoglobulin. Isr Med Assoc J 2007;9:555-556

63. Lynch A, Mariar R, Murphy J, et al. Antiphospholipid antibodies in predicting adverse pregnancy outcome. Ann Intern Med 1994;120:470-475

64. Kaira S, Tuli A, Goyal U, Choudhary R, Raheja S. Correlation of antiphospholipid antibody $\operatorname{IgM}$ with first trimester recurrent abortion. J Anat Soc India 2002;51: 10-13

65. Lockwood CJ, Omero R, Feinburg RF, Clyne LP, Coster B, Hobbins JC. The prevalence and biologic significance of lupus anticoagulant and anticardiolipin antibodies in a general population. Am J Obstet Gynecol 1989;161:369-373

66. Fialova L, Mikolikova L, Matous-Malbohan I, Benesova O, Zwinger A. Prevalence of various antiphospholipid antibodies in pregnant women. Physiol Res 2000;49:299-305

67. Branch DW, Andres R, Digre KB, Rote NS, Scott JR. The association of antiphospholipid antibodies with severe preeclampsia. Obstet Gynecol 1989;73:541-545

68. Barbui T, Cortelazzo S, Galli M, et al. Antiphospholipid antibodies in early repeated abortions: a case-controlled study. Fertil Steril 1988;50:589-592

69. Soltesz P, Veres K, Lakos G, Kiss E, Muszbek L, Szegedi G. Evaluation of clinical and laboratory features of antiphospholipid syndrome: a retrospective study of 637 patients. Lupus 2003;12:302-307

70. Konova E, Ivanova I, Petrova $\mathrm{P}$, et al. Effect of intravenous gamma-globulin therapy on lymphocyte population in pregnant women with antiphospholipid antibodies. Akush Ginekol (Sofiia) 2004;43:3-10

71. Branch DW, Peacman AM, Druzin M. A multicenter, placebo-controlled pilot study of intravenous immune globulin treatment of antiphospholipid syndrome during pregnancy. The pregnancy loss study group. Am J Obstet Gynecol 2000;182:122-127

72. Vaquero E, Lazzarin N, Valensise H. Pregnancy outcome in recurrent spontaneous abortion associated with antiphospholipid antibodies: a comparative study of intravenous immunoglobulin versus prednisone plus low dose aspirin. Am J Reprod Immunol 2001;45:174-179

73. Valensise H, Vaquero E, de Carolis C. Normal fetal growth in women with antiphospholipid syndrome treated with high 
dose intravenous immunoglobulin (IVIG). Prenat Diagn 1995;15:97-102

74. Giannakopoulos B, Passam F, Rahgozar S, Krilis SA. Current concepts on the pathogenesis of the antiphospholipid syndrome. Blood 2007;109:422-425

75. Wang S, Zhao YR, Jiao YL, et al. Increased activating killer immunoglobulin-like receptor genes and decreased specific HLA-C alleles in couples with recurrent spontaneous abortion. Biochem Biophys Res Commun 2007;360:696-701

76. Caruso AD, Carolis S, Simone N. Antiphospholipid antibodies in obstetrics: new complexities and sites of action. Hum Reprod 1999;5:267-276
77. Perricone C, Carolis CD, Giacomelli R, et al. High levels of NK cells in the peripheral blood of patients affected with antiphospholipid syndrome and recurrent spontaneous abortion: a potential new hypothesis. Rheumatology 2007;46: $1574-1578$

78. Sargent IL, Borzychowski AM, Redman CWG. NK cells and preeclampsia. J Reprod Immunol 2007;76:40-44

79. Radder CM, Roelen DL, van de Meer-Prind EM, et al. The immunologic profile of infants born after maternal immunoglobulin treatment and intrauterine platelet transfusion for fetal/alloimmune thrombozytopenia. Am J Obstet Gynecol 2004;191:815-820 